\title{
Quality characteristics of Hijikia fusiforme extracts with different extraction method
}

\author{
Yu-Ri Kwon, Kwang-Sup Youn* \\ Department of Food Science and Technology, Catholic University of Daegu, Gyeongsan 712-702, Korea
}

\section{추출방법에 따른 톳 추출물의 품질특성}

\author{
권유리 · 윤광섭* \\ 대구가톨릭대학교 식품공학전공
}

\begin{abstract}
The physiological properties of water extracts from Hizikia fusiformis extracted using different extraction methods (water extraction, WE; autoclave extraction, AE; high pressure extraction, HPE) were investigated. The freeze-dried powder yields from HPE, AE and WE were $29.33,27.84$ and $23.63 \%$, respectively. The $L^{*}$ and $b^{*}$ color values were higher in $\mathrm{WE}$, while the $\mathrm{a}^{*}$ color values were higher in $\mathrm{WE}$ and $\mathrm{AE}$. The total sugar content of $\mathrm{AE}(60.14 \%)$ was higher than those of WE (47.10\%), HPE (40.97\%). The reducing sugar content $(\mathbf{7 . 8 8 \% )}$ and protein content $(42.83 \%)$ of $\mathrm{AE}$ was higher than those of WE, and HPE. The uronic acid (5.04\%), total free amino acid (785.19 $\mathrm{mg} / \mathrm{g})$, taurine $(19.16 \mathrm{mg} / \mathrm{g})$, aspartic acid $(66.63 \mathrm{mg} / \mathrm{g})$, asparagine $(204.84 \mathrm{mg} / \mathrm{g})$, alanine $(188.87 \mathrm{mg} / \mathrm{g})$ and ammonium chloride $(243.91 \mathrm{mg} / \mathrm{g})$ contents, however, were the highest in HPE. Additionally, the crude polysaccharide yield was higher in HPE (4.75\%) than in AE and WE, and the crude saccharide (fucose, galactose, glucose, xylose and fucose) yields were higher in AE. It can be concluded that optimum conditions for the efficient extraction of Hizikia fusiformis depending on components are high pressure and a lower temperature than in the typical process.
\end{abstract}

Key words : Hijikia fusiforme, quality characteristics, high pressure extraction, polysaccharides

\section{서 론}

해조류는 다양한 기능성을 가지고 있어 식·의약 소재 개발을 위한 유용한 자원 중 하나로 평가되고 있다. 특히 해조류 중 톳(Hijikia fusiforme)은 아시아의 해안에 많이 분포하고 있으며 우리나라의 경우 제주도와 서남해안에서 많이 생산되는 갈조류로써 우수한 식이섬유소의 공급원일 뿐만 아니라 면역기능을 포함한 다양한 기능성이 있는 것으 로 알려진 중성다당류인 laminaran과 함황산성 다당류인 fucoidan이 다량 함유되어 있다(1). 또한 톳은 다시마와 더 불어 천연 정미성분인 아미노산(glutamic acid 및 aspartic

*Corresponding author. E-mail : ksyoun@cu.ac.kr

Phone : 82-53-850-3209, Fax : 82-53-850-3209

Received 1 October 2014; Revised 9 December 2014; Accepted 19 December 2014

Copyright (c) The Korean Society of Food Preservation. All rights reserved. acid)과 식이성 섬유소 및 칼슘, 철분 등 무기질이 풍부하여 다양한 식품에 적용 가능한 소재이다(2). 최근에는 해조류 의 생리활성 물질을 이용한 기능성 식품으로서의 활용에 대한 관심이 높아져가는 추세이다. 따라서 국내 해조류 가 공산업의 낙후성 및 취약성을 극복하기 위해서는 고부가가 치 제품화가 요구되고 있으나, 현재 해조류 가공은 주로 단순가공에 의존하고 있으며 해조가공제품은 다른 가공품 에 비해 비린내 및 비린맛 등의 단점을 가지고 있어 소비자 들의 기호도를 저하시키거나 다양한 용도 개발의 어려움 등 고부가가치 제품화에 대한 문제점을 가지고 있다. 따라 서 해조류 가공 시 단점을 보안할 수 있는 다양한 가공공정 에 관한 연구가 진행되어야 한다(3).

해조류 가공 시 물질의 특성으로 단단한 조체와 세포벽 충전 물질인 세포간 다당의 유용성분을 추출하기가 어렵 고, 추출을 하더라도 많은 비용을 필요로 한다. 일반적으로 해조류의 유용성분을 추출할 때에는 열수 추출이나 산, 알 칼리 또는 효소처리 등에 의하여 추출하는 방법을 사용하고 
있다(4). 하지만 해조류의 경우, 열이나 산 처리에 의한 추출 및 정제 방법은 유효 성분의 활성에 영향을 미치며 추출 및 가공 방법에 따라 다당류의 화학적 특성이 달라지며(5), 효소추출 시 물리화학적인 추출에 비해 많은 비용이 드는 단점을 가지고 있다. 따라서 해조류 가공의 산업화를 위하 여 유용성분 및 추출물의 수율을 높일 수 있는 다양한 추출 방법에 관한 연구가 필요한 실정이다.

한편, 천연물 추출에 사용된 전통적인 방법은 추출 효율 이 낮고 에너지 소비가 많으며 열로 인한 많은 유용성분의 파괴, 단백질의 변이, 성분의 손실, 가용성분 위주의 추출, 열에 대하여 불안정한 것 등의 단점을 드러내고 있어(6), 이를 극복하기 위하여 다양한 추출방법들이 식품에 적용되 고 있다. 열처리를 이용하는 방법 중에는 가압 열처리가 있다. 열과 압을 가하여 추출하는 방법이나 영양소의 파괴 및 생리활성물질의 손실 등의 문제점들이 발생되어 가공방 법을 제한적으로 사용되고 있다(7). 그러나 최근에는 가압 열처리를 통해 다양한 화학적 변화가 일어나며 이로 인해 생리활성 물질이 증가한다는 연구가 보고(8)된 바 있어 적 절한 가압처리 조건은 물질의 수율과 유용물질의 추출에 도움이 될 것으로 판단된다. 또한 다양한 추출 방법 중 비 열처리 방법이 있으며, 그 중 초고압 추출은 최근 식품에서 주목받고 있는 가공기술 분야로서 기존 공정보다 식품의 보존성과 물성, 기능성을 향상시켜주는 장점이 있으며 $100 \sim 1,000 \mathrm{MPa}$ 의 압력을 이용한 압력매체로 물이나 오일 에 압력을 순간적으로 균일하게 전달시키는 원리로서 기존 의 열처리 공정은 화학변화가 많이 일어나는데 반하여 초고 압 공정은 화학적으로 큰 변화를 일으키지 않은 장점이 있다(9). 또한 초고압 기술은 생리활성 성분의 활성 수준을 유지하기 위해서 생리활성 조성물을 가압 처리하는 방법 등의 목적과 다르다. 단백질의 경우 적용 압력에 따라 변성 의 정도가 달라지고 단백질의 변성 또는 변형, 효소활성화 또는 불활성화, 효소 기질 특이성 변화, 탄수화물과 지방의 특성 변화 등을 유도하고 고압하에서는 부피가 줄어드는 방향으로 화학반응이 촉진되고, 소수성결합이나 이온결합 의 파괴를 촉진하고 분자량이 작은 물질보다는 소수성 결합 등을 포함하는 거대분자에 대해 선택적으로 작용한다 $(10,11)$. 따라서 초고압 기술은 보존성 연장 이외에도 가수 분해, 유용성분 추출, 생산효율 증대 등 산업적 적용이 가능 하다.

따라서, 본 연구에서는 해조류 톳의 수율 증대 및 유용활 성물질의 손실을 최소화를 위해 다양한 추출(열수, 가압가 열, 초고압) 공정을 이용하여 품질 분석을 실시하였으며 이를 통해 톳의 효과적인 추출방법을 제시하고, 산업화에 적용할 기술 활용을 위한 기초자료를 제공하고자 하였다.

재 료

\section{재료 및 방법}

본 실험에 사용된 톳은 2013년 4월에 전남 완도군 (주)금
일수산에서 구입하여 사용하였으며, 물로 3 4회 수세하여 염분과 이물을 제거하고 건조 후 분쇄하여 사용하였다.

\section{추출물의 제조}

톳의 추출방법은 톳 건조분말에 15 배 부피의 증류수를 가한 후 열수추출(water extraction, $\mathrm{WE}$ ), 가압가열추출 (autoclave extraction, $\mathrm{AE}$ ), 초고압 추출(high-pressure extraction, HPE)로 추출물을 제조하였다. 열수추출(WE)은 플라스크에 건조분말 $100 \mathrm{~g}$ 에 증류수 $1,500 \mathrm{~mL}$ 를 가한 후 $80^{\circ} \mathrm{C}$ 에서 3 시간씩 3 회 반복하여 추출하였다. 가압가열추출 은 autoclave(DF-100A, DOORI Scientific Co., Gyeonggi, Korea)를 이용하여 $121^{\circ} \mathrm{C}$ 에서 15 분 동안 추출하였으며, 초 고압 추출(HPE)은 건조분말 $100 \mathrm{~g}$ 에 증류수 $1,500 \mathrm{~mL}$ 을 비닐 팩에 함께 넣어 공기가 들어가지 않도록 밀봉과 동시 에 초고압 장치((TFS-SL, TOYO KOTASU Co., LTD., Japan)를 이용하여 수차례의 예비실험 결과를 바탕으로 $100 \mathrm{MPa}, 50^{\circ} \mathrm{C}$ 의 조건으로 5 시간 동안 추출하였다. 각각의 추출물은 Whatman No. 1 여과지로 여과 후 감압농축기 (rotary vacuum evaporator N-N series, Eyela, Tokyo, Japan) 로 농축한 후에 동결건조(FD SFDSM12, Samwon, Korea)하 여 분말을 제조하였으며, $-50^{\circ} \mathrm{C}$ 에 저장하면서 실험에 사용 하였다. 추출물의 수율은 추출물을 동결 건조하여 건물 중 량을 구한 다음 추출액 조제에 사용한 원료 건물량에 대한 백분율로 계산하였다.

\section{색 도}

색도는 색차계(Chromameter CR-200, Minolta, Tokyo, Japan)로 측정하였으며, 밝기를 나타내는 L(lightness), 적색 도를 나타내는 $\mathrm{a}$ (redness), 황색도를 나타내는 b(yellowness) 를 측정하였다.

\section{전당 및 환원당 함량}

전당 함량은 phenol-sulfate acid법(12)에 따라 측정하였 다. 즉 시료 $1 \mathrm{~mL}$ 에 $5 \%$ phenol $1 \mathrm{~mL}$ 와 sulfuric acid $5 \mathrm{~mL}$ 를 가하여 발색시킨 다음 20 분간 방치 후 spectrophotometer (UV1601, Shimadzu, Japan)를 이용하여 $470 \mathrm{~nm}$ 에서 흡광도 를 측정하였다. 총당의 정량은 glucose 표준품을 사용하여 검량선을 작성하여 실시하였다. 환원당은 dinitrosalicylic $\operatorname{acid}(\mathrm{DNS})$ 법으로 측정하였다. 10 배 희석한 시료 희석액 1 $\mathrm{mL}$ 에 $\mathrm{DNS}$ 시약 $3 \mathrm{~mL}$ 을 가하여 잘 교반한 후 끓는 물에서 5 분간 반응시켰다. 반응액을 냉각 후 $550 \mathrm{~nm}$ 에서 흡광도를 측정하였으며, 이 측정치를 glucose로 환산하여 표시하였 다.

\section{단백질 함량}

단백질 함량은 Lowry법(13)에 따라 측정하였다. 실험 전 에 $\mathrm{A}$ (증류수 $100 \mathrm{~mL}$ 에 $0.5 \mathrm{~g} \mathrm{CuSO} \cdot 5 \mathrm{H}_{2} \mathrm{O}$ 와 $1 \mathrm{~g}$ 
$\mathrm{Na}_{3} \mathrm{C}_{6} \mathrm{H}_{5} \mathrm{O}_{7} \cdot 2 \mathrm{H}_{2} \mathrm{O}$ 용해) 및 $\mathrm{B}$ (증류수 $1 \mathrm{~L}$ 에 $20 \mathrm{~g} \mathrm{Na}_{2} \mathrm{CO}_{3}$ 와 $4 \mathrm{~g} \mathrm{NaOH}$ 용해) 용액을 제조하였다. 시료 $0.5 \mathrm{~mL}$ 에 2.5 $\mathrm{mL}$ 의 $\mathrm{C}(1 \mathrm{~mL} \mathrm{~A}$ 용액과 $50 \mathrm{~mL} \mathrm{~B}$ 용액 $)$ 용액을 가한 후 10 분간 실온에 방치하였다. 그 후, $\mathrm{D}(10 \mathrm{~mL}$ Folin-Ciocalteu phenol reagent와 $10 \mathrm{~mL}$ 증류수)용액 $0.25 \mathrm{~mL}$ 을 가하여 혼합한 후 20 분간 실온에 방치한 다음 spectrophotometer (UV1601, Shimadzu, Japan)를 이용하여 $750 \mathrm{~nm}$ 에서 흡광도 를 측정하였다. 표준곡선은 bovine serum albumin(Sigma, St. Louis, MO, USA)를 이용하여 검량곡선을 작성한 후 함량 계산에 활용하였다.

\section{우론산 함량}

우론산 함량은 증류수에 용해되어 있는 시료 $200 \mu \mathrm{L}$ 를 cap tube에 분취하고 $4 \mathrm{M}$ ammonium sulfate $20 \mu \mathrm{L}$ 를 가하여 혼합하였다. 진한 황산에 $25 \mathrm{mM}$ 의 농도로 용해시킨 sodium tetraborate $1 \mathrm{~mL}$ 를 첨가한 뒤 $100^{\circ} \mathrm{C}$ 에서 5 분간 가열하고 실온에서 방냉하였다. 시험관의 방냉이 적절히 이루어지면 $0.1 \%$ cabazole 용액을 $40 \mu \mathrm{L}$ 가하고 다시 $100^{\circ} \mathrm{C}$ 에서 15 분간 반응시켜 준 다음 방냉한 후 $520 \mathrm{~nm}$ 에서 흡광도를 측정하 였다. Uronic acid 함량은 D-glucuronic acid로 작성한 검량 곡선으로 계산하였다(14).

\section{유리아미노산 함량}

각각의 조건에서 추출한 톳의 동결건조분말 $1 \mathrm{~g}$ 에 $70 \%$ ethanol $10 \mathrm{~mL}$ 를 가하여 24시간 동안 추출과정을 거친 후 $3,000 \mathrm{rpm}$ 에서 20 분간 원심분리 하여 상등액을 취하였다. 상등액은 감압농축기(rotary vacuum evaporator N-N series, Eyela, Tokyo, Japan)로 감압농축하여 용매를 휘발시킨 후 아미노산 분석용 lithium citrate loading buffer로 용해시키 고, $0.22 \mu \mathrm{m}$ membrane filter(Millipore Co.)로 여과하여 아미 노산 자동분석기(Biochrom 30+ amino acid analyzer, Biochrom, Cambridge, $\mathrm{UK})$ 로 분석하였다.

\section{조다당류의 제조}

열수추출, 가압가열추출, 초고압추출을 통하여 제조된 추출물로부터 조다당류를 분리하기 위해 에탄올을 이용하 여 다당류 성분을 침전시켰다. 총 두 차례에 걸쳐 반복적으 로 수용화 및 에탄올 침전을 실시하였으며 이를 통해 조다 당류 이외의 물질을 제거하고 부분 정제된 시료로 이용하고 자 침전물을 동결건조(FD SFDSM12, Samwon, Seoul Korea)하여 실험에 이용하였다. 조다당류의 수율은 동결 건조하여 건물 중량을 구한 다음 추출액 조제에 사용한 원료 건물량에 대한 백분율로 계산하였다.

\section{구성당 분석}

$1 \sim 2 \mathrm{mg}$ 의 동결건조한 조다당류를 $2 \mathrm{M}$ 의 trigluoroacetic $\operatorname{acid}(\mathrm{TFA})$ 에 넣고 $110^{\circ} \mathrm{C}$ 에서 24 시간 동안 산 가수 분해
시키고 여과 $(0.2 \mu \mathrm{m})$ 및 희석한 뒤 이를 Table 1 과 같은 조건으로 분석하였다. 분석시스템은 High performance anion exchange chromatography(HPAEC, ICS-3000, Donex Co., USA)이며 컬럼의 종류는 CarboPac ${ }^{\mathrm{TM}} \mathrm{PA}-1(250 \times 4 \mathrm{~mm}$, Dionex Co., USA)이다. $30^{\circ} \mathrm{C}$ 에서 $18 \mathrm{mM} \mathrm{NaOH}$ 를 이동상으 로 하여 유속 $1.0 \mathrm{~mL} / \mathrm{min}$ 로 흘렸으며, 칼럼의 온도는 $25^{\circ} \mathrm{C}$ 로 설정하고, 가수분해 된 시료의 주입량은 $15 \mu \mathrm{L}$ 이다. 정량을 위한 표준 구성당은 L-fucose, L-rhamnose, D-arabinose, D-galactose, D-glucose, D-mannose, D-xylose를 사용하였다.

Table 1. Analytical conditions of ion exchange chromatography for sugar compositions

\begin{tabular}{ll}
\hline \multicolumn{1}{c}{ Item } & \multicolumn{1}{c}{ Condition } \\
\hline Instrument & HPAED (ICS-3000, Dionex Co., USA) \\
Eluent & $18 \mathrm{mM} \mathrm{NaOH}$ \\
Column & Carbopac $^{\mathrm{TM}}$ PA-1 $(250 \times 4 \mathrm{~mm}$, Dionex Co., USA $)$ \\
Flow rate & $1.0 \mathrm{~mL} / \mathrm{min}$ \\
Injection volume & $15 \mu \mathrm{L}$ \\
Temperature & $25^{\circ} \mathrm{C}$ \\
Detector & HPAED-PAD, ED50 \\
\hline
\end{tabular}

\section{통계처리}

유리아미노산 함량 및 구성당 분석을 제외한 모든 실험 은 3회 반복으로 행하여 평균치와 표준편차로 나타내었고, 유의성 검증은 SPSS software(12, SPSS Inc., Chicago, IL, USA)을 이용하여 Duncan's multiple range test를 행하였다.

\section{결과 및 고찰}

추출방법에 따른 톳 추출물의 수율 및 색도

추출방법을 달리한 톳 추출물의 수율 및 색도 결과는 Table 2 와 같이 나타내었다. 산업적 측면에서 볼 때 천연물 의 추출수율 증가는 부가가치적 측면에서 매우 중요한 요소 로 작용한다. 추출방법에 따른 톳 추출물의 수율을 비교한 결과, 초고압(HPE, 29.33\%), 가압가열( $\mathrm{AE}, 27.84 \%)$, 열수 (WE, 23.64\%) 추출의 순으로 나타났으며, 특히 초고압 추출 의 경우 기본적인 열수 추출물보다 약 $6 \%$ 정도 수율이 향상되었으며 이는 $\mathrm{Kim}$ 등(10)의 결과와 일치하는 경향을 나타내었다. 이는 초고압 처리를 통하여 시료의 조직과 세 포벽에 변형이 일어나고 세포 내에서 용매의 투입이 용이해 지면서 기존 물질들의 용출량이 증가한 결과로 사료되며 (15), 이는 Choi와 Lee(16)의 연구 결과와 일치하는 경향을 나타내었다. 한편, 색도에서는 밝기를 나타내는 $\mathrm{L}$ 값과 황색 도를 나타내는 $\mathrm{b}$ 값의 경우 열수 추출물에서 높은 값을 보였 으며 가압가열 추출물의 경우 높은 적색도와 낮은 명도 및 황색도를 나타내었다. Kwon과 Youn(7)의 보고에 따르 
면 열수 및 고온고압 추출한 미역 및 다시마 추출물 색도의 경우, 가압가열 추출물이 열수 추출물에 비해 낮은 명도와 황색도를 나타내어 본 연구 결과와 동일한 결과를 나타내었 다. 갈조류에는 fucoxanthin이라는 carotenoid 색소가 함유 되어 있으며 이는 가열처리 시 톳의 색소 용출이 용이해지 는 것으로 사료된다.

Table 2. Yield and Hunter's color value of Hijikia fusiforme extracts with different extraction methods

\begin{tabular}{ccccc}
\hline \multirow{2}{*}{ Sample $^{1)}$} & \multirow{2}{*}{$\begin{array}{c}\text { Yield } \\
\left(\%, \mathrm{DB}^{2}\right)\end{array}$} & \multicolumn{3}{c}{ Color } \\
\cline { 3 - 5 } & Lightness (L) & Redness (a) & Yellowness (b) \\
\hline $\mathrm{WE}$ & $23.64 \pm 0.10^{3)(4)}$ & $58.43 \pm 0.57^{\mathrm{a}}$ & $2.91 \pm 0.08^{\mathrm{a}}$ & $10.06 \pm 0.23^{\mathrm{a}}$ \\
$\mathrm{AE}$ & $27.84 \pm 0.01^{\mathrm{a}}$ & $54.14 \pm 0.43^{\mathrm{c}}$ & $2.97 \pm 0.15^{\mathrm{a}}$ & $7.36 \pm 0.10^{\mathrm{c}}$ \\
$\mathrm{HPE}$ & $29.33 \pm 0.02^{\mathrm{b}}$ & $56.96 \pm 1.44^{\mathrm{b}}$ & $2.58 \pm 0.07^{\mathrm{b}}$ & $9.58 \pm 0.21^{\mathrm{b}}$ \\
\hline
\end{tabular}

${ }^{1)} \mathrm{WE}$, water extraction; $\mathrm{AE}$, autoclave extraction; HPE, high-pressure extraction.

${ }^{2)} \mathrm{DB}$ : dry basis.

${ }^{3)}$ Values are means \pm standard deviations of triplicate determinations.

${ }^{4)}$ Different superscripts within a column $(\mathrm{a}-\mathrm{c})$ indicate significant differences $(\mathrm{p}<0.05)$.

\section{톳 추출물의 구성성분 분석}

초고압, 열수 및 가압가열 추출방법을 이용하여 톳 추출 물의 전당, 환원당, 우론산 및 단백질 함량을 측정한 결과는 Table 3 과 같다. 추출방법에 따른 톳의 구성성분 분석 결과, 전당의 경우 전체적으로 $40 ~ 60 \%$ 의 높은 함량을 나타내었 으며, 특히 가압가열 추출물에서 $60.14 \%$ 로 높은 함량을 보였으며, 열수 추출물, 초고압 추출물의 순으로 나타났다. $\mathrm{Na}$ 등(17)의 연구에서는 아임계 추출법을 이용하여 추출한 해조류의 전당 함량을 측정한 결과, 톳 열수 추출물이 32.8 42.7 \%정도 나타내어 본 실험결과와 비교해 볼 때 낮은 함량을 나타내었으나 압과 열을 가했을 경우 전당 함량이 높아진다는 경향은 본 연구와 유사한 결과를 나타내 었다. 또한 환원당 및 단백질 함량의 경우, 전당의 결과와 유사한 경향을 나타내었으며 가압가열, 열수, 초고압 추출 의 순으로 함량을 나타내었다. 물을 이용한 고온 추출 공정 시 시료가 받는 온도와 수증기 압력이 증가함에 따라 상온 에서 반응하는 일반 물과 다르게 반응하여 유전상수는 감소 하고 이온강도는 증가한 상태가 되어 해조류에서 당 가수분 해 반응을 유발할 수 있다(18-20). 이런 원리를 이용하여 해조류의 세포벽이 파괴되고 물의 출입이 용이하여 시료의 당화성분 추출이 가능하며, 불순물이 없고 추출 효율을 증 진시킬 수 있다. 따라서 톳의 경우 복합 다당류 형태로 구성 되어 있기 때문에 적절한 온도를 통해 해조류의 유용성분의 추출을 용이하게 조절 할 수 있다. 한편, 해조류 중 갈조류는 식이섬유를 약 32 75\% 함유하고 있으며 그 중 51 85\%가 수용성 식이섬유로 구성되어 있다. 이러한 해조류에 함유 된 식이섬유와 다당류는 혈압 강하작용, 혈중 콜레스테롤 저하효과, 종양세포의 성장 저해 효과, 항 혈액응고 효과 등이 있다고 알려져 있다(21-23). 이를 통해 전당 함량이
높을수록 해조류 내 다양한 기능성 다당류의 함량이 많으 며, 이러한 결과를 보아 가압가열 추출방법은 해조류 내 기능성 물질을 좀 더 효과적으로 추출할 수 있는 방법으로 사료된다.

해조류 다당류 중 기능성 다당인 fucoidan은 함황 산성 다당으로써 조체내에서 우론산과 acetyl group 및 단백질을 포함하기도 하며 각기 다른 복잡한 구조의 fucoidan이 존재 하고 있다(24). 따라서 황산기를 함유한 fucose, rhamnose, xylose, glucuronic acid 등의 당분석을 통해 산성다당의 존 재 및 함량을 예측 할 수 있다. 또한 우론산은 단당류 분자의 말단에 있는 제 1 급 알콜기가 산화되어 carboxyl기가 된 것으로 6탄당에서 유도되는 uronic acid가 중요하다. 식물계 에서는 glucoronic acid가 식물 검질의 중요한 구성성분으로 존재하며 동물체내에서는 홀로 존재하기도 하며 phenol계 의 독성 물질이 생기면 glucuronic acid와 결합하여 무독한 공액 glucuronide를 형성하여 소변으로 배설되고 중성 다당 체에 비해 면역체계에 미치는 영향이 크다(25). 우론산의 경우 초고압 추출물이 $5.04 \%$ 로 높은 함량을 보였으며 가압 가열, 열수 추출물의 순으로 나타나 압력 공정을 통해 톳의 세포벽 성분 다당체 및 이의 결합을 붕괴하여 추출이 높아 진 것으로 판단되나(26), 가압가열 추출물은 $4.87 \%$ 로 초고 압 추출물과 큰 함량차이를 나타내지 않아 유용 당성분 추출은 온도와 압력이 적재적소에 따라 적정 조건이 필요한 것으로 판단되며 이는 고압과 고온일수록 추출 효율을 높일 수 있다는 보고(27,28)와 일치하는 경향을 나타내었다.

Table 3. Determination of total sugar, reducing sugar, uronic acid and protein contents from Hijikia fusiforme extracts

(unit : \%)

\begin{tabular}{ccccc}
\hline Sample $^{1)}$ & Total sugar & Reducing sugar & Uronic acid & Protein content \\
\hline $\mathrm{WE}$ & $47.10 \pm 2.44^{2 \mathrm{bb} 3)}$ & $5.90 \pm 0.17^{\mathrm{b}}$ & $3.73 \pm 0.14^{\mathrm{c}}$ & $36.50 \pm 1.88^{\mathrm{b}}$ \\
$\mathrm{AE}$ & $60.14 \pm 2.80^{\mathrm{a}}$ & $7.88 \pm 0.19^{\mathrm{a}}$ & $4.87 \pm 0.01^{\mathrm{b}}$ & $42.83 \pm 1.11^{\mathrm{a}}$ \\
$\mathrm{HPE}$ & $40.97 \pm 2.91^{\mathrm{c}}$ & $4.31 \pm 0.10^{\mathrm{c}}$ & $5.04 \pm 0.09^{\mathrm{a}}$ & $21.36 \pm 1.01^{\mathrm{c}}$ \\
\hline
\end{tabular}

${ }^{1)} \mathrm{WE}$, water extraction; $\mathrm{AE}$, autoclave extraction; $\mathrm{HPE}$, high-pressure extraction.

${ }^{2}$ Values are means \pm standard deviations of triplicate determinations.

${ }^{3}$ Different superscripts within a column $(a-c)$ indicate significant differences $(\mathrm{p}<0.05)$.

\section{톳 추출물의 아미노산 함량}

아미노산은 화학구조에 따라 여러 형태로 존재하며, 주 로 단백질을 구성하고 있는 것과 유리된 형태로 존재한다. 또한 아미노산의 결합 형태에 따라 여러 개가 연결된 펩타 이드, 당, 또는 지지로가 결합되어 있는 복합단백질 등의 형태로도 미량 존재한다. 아미노산은 영양 성분 뿐만 아니 라 맛 성분에 기여하는데, 특히 유리 아미노산이 핵산관련 성분과 함께 맛에 중요한 역할을 한다. 유리아미노산은 생 리활성 물질의 구성 성분일 뿐만 아니라 정미성분으로 중요 하며, 수산물에 있어 아미노산의 증가는 맛을 상승시키는 
(A)

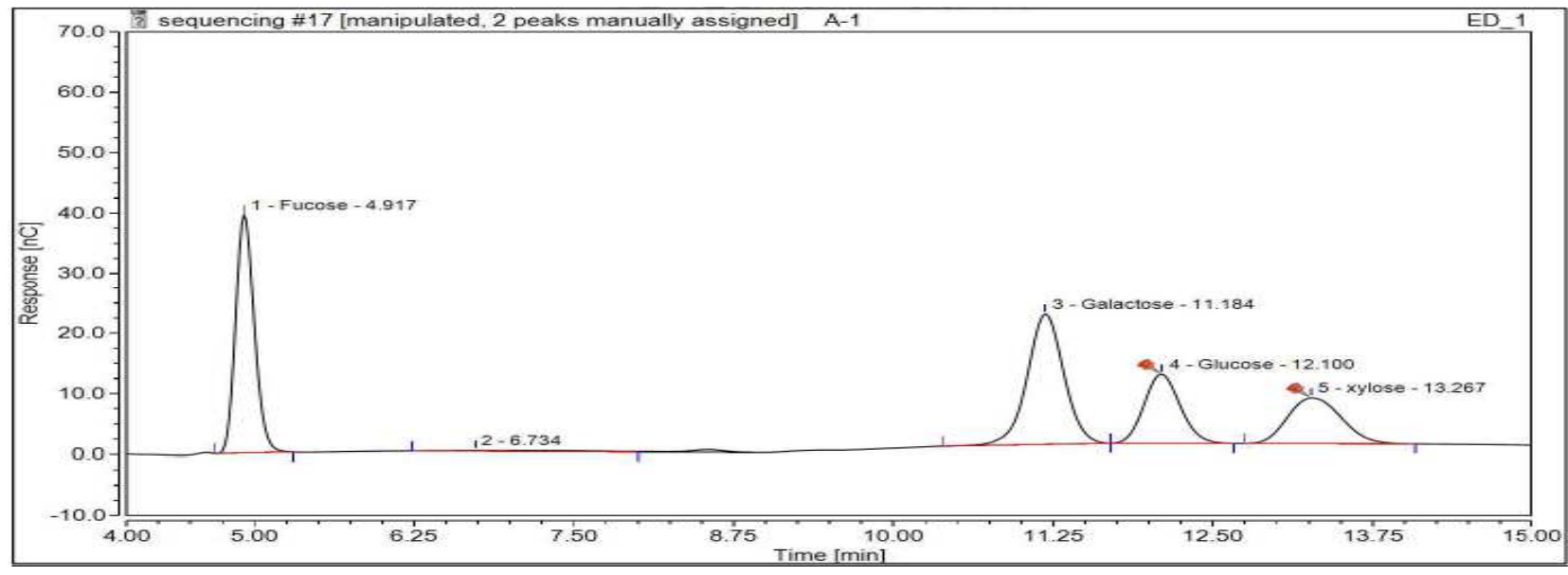

(B)

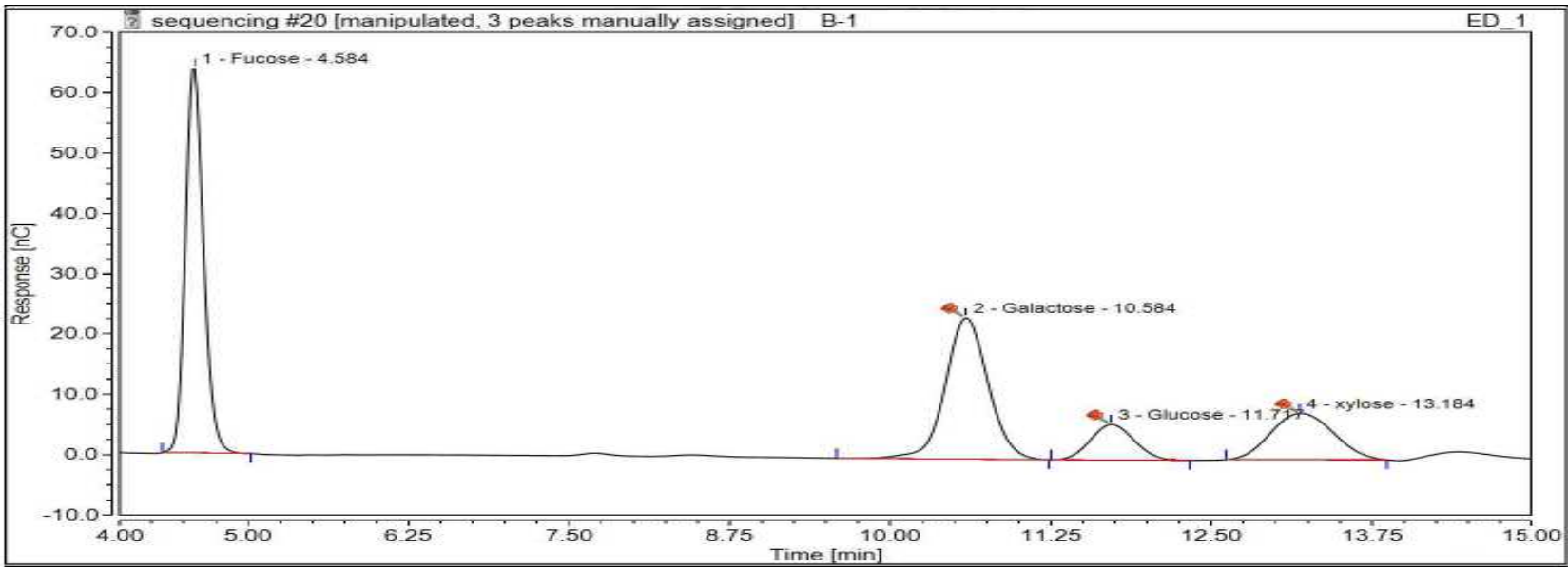

(C)

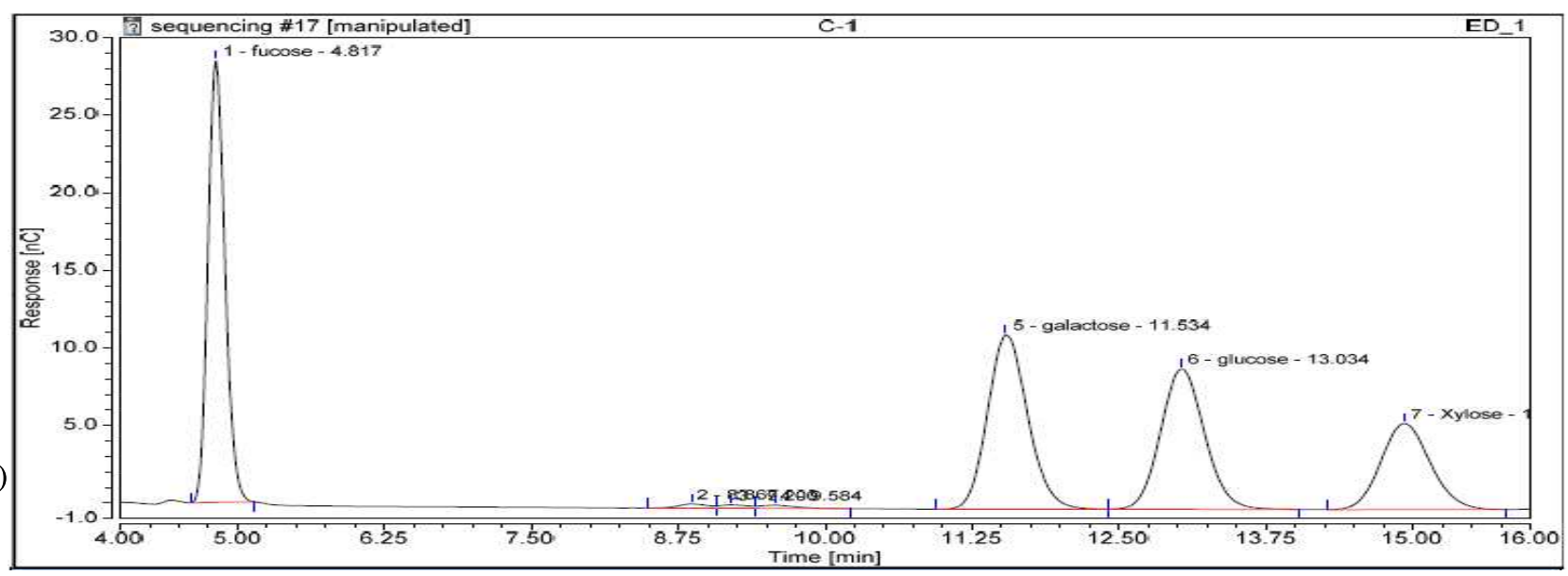

Fig. 1. Monosaccharides composition of crude polysaccharides analyzed by fully acid-hydrolysis and detected using HPACE-PAD (A), water extraction; (B), autoclave extraction; (C), high-pressure extraction.

중요한 역할을 하는 것으로 알려져 있다(29). 따라서 톳 추출방법별로 아미노산의 함량을 분석해 본 결과(Table 4), 전체적으로 유리 아미노산으로는 taurin, aspartic acid, asparagine, glutamic acid 등이 검출되었으며 총 아미노산의 함량은 초고압(HPE) > 열수(WE) > 가압가열(AE) 추출물의
순으로 나타나 초고압 추출 시 구성 아미노산의 함량이 증가됨을 알 수 있었다. 갈조류인 김이나 미역, 다시마 등의 주요 아미노산은 alanine, aspartic acid, glutamic acid 등 인 것으로 보고되어 있어 본 연구 결과와 일치하는 경향을 나타내었다(30,31). 또한 asparagine은 초고압 추출물 
$(204.84 \mathrm{mg} / \mathrm{g})$ 에서만 검출되었으며, 감칠맛과 단맛을 내는 아미노산 glutamic acid, aspartic acid와 alanine의 경우 초고 압 추출물에서 높은 함량을 나타내어 추후 초고압 추출을 이용하여 천연조미료의 제조가 가능한 것으로 사료된다.

Table 4. Amino acid content of Hijikia fusiforme extracts with different extraction methods

(Unit : $\mathrm{mg} / \mathrm{g}$ dry basis)

\begin{tabular}{|c|c|c|c|}
\hline \multirow{2}{*}{$\begin{array}{l}\text { Amino acids and its } \\
\text { derivatives }\end{array}$} & \multicolumn{3}{|c|}{ Extraction method ${ }^{1)}$} \\
\hline & WE & $\mathrm{AE}$ & HPE \\
\hline Taurine & 16.11 & 10.09 & 19.16 \\
\hline L-Aspartic acid & 16.55 & 3.83 & 66.63 \\
\hline L-Asparagine & $\mathrm{ND}$ & $\mathrm{ND}$ & 204.84 \\
\hline L-Glutamic acid & 100.86 & $\mathrm{ND}$ & 61.78 \\
\hline L-Alanine & 122.78 & 84.97 & 188.87 \\
\hline Ammonium chloride & 184.37 & 135.50 & 243.91 \\
\hline Total amino acids & 400.67 & 234.38 & 785.19 \\
\hline
\end{tabular}

${ }^{11} \mathrm{WE}$, water extraction; $\mathrm{AE}$, autoclave extraction; HPE, high-pressure extraction.

\section{톳 추출물의 유래 조다당류의 품질특성}

추출방법에 따른 톳의 조다당류의 수율과 구성당 함량 및 분석을 나타낸 결과는 Table 5, Fig. 1과 같다. 추출물에 3 배 가량의 에탄올을 이용하여 침전되는 조다당류를 분리 하여 동결건조를 실시하였다. 그 결과, 초고압 추출물 $(\mathrm{HPE})$ 에서 $4.75 \%$ 로 가장 높게 나타났으며 가압가열(AE), 열수 (WE) 추출물의 순으로 나타났다. 높은 압력을 이용하여 추출할 경우 세포벽이 무너지고 단백질의 변성이 일어나면 서 다양한 물질의 용출이 일어나게 된다. 따라서 조다당류 추출 시 에탄올 침전을 실시하게 되는데, 이때 당물질 이외 의 변성된 단백질과 같은 불순물의 침전도 일어나며, 전체 적으로 유용성분 이외의 다양한 물질의 추출이 일어난 초고 압 추출물의 수율이 높은 것으로 판단된다. 한편 추출방법 에 따른 조다당류의 주요 구성 성분을 분석하고자 high performance anion exchange chromatography를 이용하여 구 성당 분석 결과, 주요 구성당 성분으로는 fucose, galactose, glucose, xylose 순으로 나타났으며 이는 Baek 등(1)의 연구 와 유사한 경향을 보였다. 전체적으로 가압가열추출한 수 용성 다당에서 $85.81 \mu \mathrm{g} / \mathrm{mg}$ 으로 당 수율이 높았고 열수추출 $(61.75 \mu \mathrm{g} / \mathrm{mg})$, 초고압 추출 $(60.1 \mu \mathrm{g} / \mathrm{mg})$ 의 순으로 나타났으 며 구성하는 당의 함량은 다르게 나타났다. 이러한 결과를 통하여 동일한 원재료로부터 분리를 실시하였으나 추출방 법에 따라 서로 다른 당 조성비를 가지고 있음을 확인하였 다. 한편, 조다당류의 수율과 구성당 함량의 차이가 나는 것은 구성당 분석 시 전처리(정제)를 실시하는데 이때 조다 당류에 함유되어 있던 불순물 제거가 일어난 것으로 판단된 다. 또한 해조류의 유용 당성분의 추출은 높은 온도에서 많은 양이 용출되므로 단순 수율과는 차이를 나타내는 것을
알 수 있었다. 다당체는 중성 다당체 및 산성다당체로 나뉘 는데 산성다당체는 알콜 불용성 성분으로 galacturonic acid 가 $60 \%$ 정도 차지하고 arabinose, rhamnose, glucose, 및 galactose 등이 측쇄를 구성하고 있다(26). 우론산의 함량 측정 시 초고압 추출물과 가압가열 추출물에서 높은 함량을 나타내었으며 구성당 분석 결과 함께 결합하고 있는 glucose 및 galactose의 함량 또한 높게 나타나 산성 다당체 구성 비율이 높은 것으로 판단된다. 또한 전체적으로 각 추출물에서 높은 함량을 나타낸 fucose가 주요한 당 성분이 라는 결과는 톳 유래 다당류의 구성 성분이 fucose를 포함하 는 fucoidan 성분을 포함하고, 또한 여러 단당으로 구성된 복합 다당임을 알 수 있었다(1).

Table 5. Yield and chemical compisitions of crude polysaccharides by various extraction method of Hizikia fusiform.

\begin{tabular}{cccccc}
\hline Sample $^{1)}$ & Yield $(\%)$ & $\begin{array}{c}\text { Fucose } \\
(\mu \mathrm{g} / \mathrm{mg})\end{array}$ & $\begin{array}{c}\text { Galactose } \\
(\mu \mathrm{g} / \mathrm{mg})\end{array}$ & $\begin{array}{c}\text { Glucose } \\
(\mu \mathrm{g} / \mathrm{mg})\end{array}$ & $\begin{array}{c}\text { Xylose } \\
(\mu \mathrm{g} / \mathrm{mg})\end{array}$ \\
\hline $\mathrm{WE}$ & 2.88 & 25.52 & 20.74 & 10.64 & 9.63 \\
$\mathrm{AE}$ & 3.12 & 39.31 & 28.55 & 6.98 & 10.67 \\
$\mathrm{HPE}$ & 4.75 & 22.56 & 16.38 & 13.24 & 7.92 \\
\hline
\end{tabular}

${ }^{11} \mathrm{WE}$, water extraction; $\mathrm{AE}$, autoclave extraction; HPE, high-pressure extraction.

\section{요 약}

본 연구에서는 다양한 추출방법(열수, 가압가열, 초고압 추출방법)을 통해 톳 추출물을 제조하였으며 품질특성을 실시하여 효과적인 톳 추출방법을 제시하고자 하였다. 추 출 수율은 초고압 추출물, 가압가열 추출물, 열수 추출물 순으로 높은 수율을 확인하였으며 색도의 경우 열수 추출물 에서 높은 명도와 황색도를 나타내었고 가압가열 추출물에 서는 적색도가 높았다. 추출방법에 따른 톳 추출물의 전당 함량을 측정한 결과, 전체적으로 모든 추출물이 $40 ~ 60 \%$ 의 높은 전당 함량을 보였으며 특히 가압가열 추출물의 함량이 높았다. 또한 시료별 전당 함량의 경우 가압가열, 열수, 초고 압 추출물의 순으로 높은 함량을 보였으며 이는 환원당과 단백질 함량에서도 동일한 결과를 나타내었다. 그러나 우 론산 및 총 아미노산 함량의 경우 초고압 추출물이 다른 추출물보다 높은 함량을 보였으며, 특히 asparagine의 경우 초고압 추출물에서만 검출되었다. 톳의 다당류 성분을 알 아보고자 에탄올을 이용하여 조다당류를 추출한 결과 수율 의 경우 초고압 추출물에서 $4.75 \%$ 로 높았으며 가압가열, 열수 추출물의 순으로 나타났다. 또한 high performance anion exchange chromatography를 통하여 조다당류의 구성 당을 살펴본 결과 fucose가 주 당성분인 polysaccharide임을 알 수 있었으며 galactose, glucose, xylose가 함유되어 있음 을 알 수 있었다. 이러한 결과를 종합해 볼 때 높은 온도와 
압력을 가해 추출할 경우 해조류의 수율 및 유용성분의 추출이 용이해짐을 알 수 있었으며 추후 적절한 압력과 온도 설정관련 연구를 통해 해조 가공산업에 유용할 것으로 판단된다.

\section{감사의 글}

본 연구는 산업통상자원부 지정 대구가톨릭대학교 해양 바이오산업연구센터(RIC)의 지원에 의한 것입니다.

\section{References}

1. Baek G, Goo BG, Ahn BJ, Park JK (2013) Effects of water-soluble polysaccharides from Tott on lipid absorption and animal body weight. J Korean Soc Food Sci Nutr, 42, 556-562

2. Kim JH, Song HS, Yang JY (2012) Nutritional characteristics of Kochujang added with fermented extracts of Hizikia fusiforme. J Food Hyg Safety, 27, 473-478

3. Kim SJ, Moon JS, Kang SG, Jung ST (2003) Extraction of porphyran from decolored laver. Korean J Food Sci Technol, 35, 1017-1021

4. Song BB, Kim SK, Jeong GT (2011) Enzymatic hydrolysis of marin algae Hizikia fusiforme. Korean Soc Biotechnol Bioeng J, 26, 247-351

5. Ponce NMA, Pujol CA, Damonte EB (2003) Fucoidans from the brown seaweed Adenocystis utricularis : extraction methods, antiviral activity and structural studies. Carbohydr Res, 338, 153-165

6. Park JH, Lee HS, Mun HC, Kim DH, Seong NS, Jung HG, Bang JK, Lee HY (2004) Effect of ultrasonification process on enhancement of immuno-stimulatory activity of Ephedra sinica Stapf and Rubus coreanus Miq. Korean J Biotechnol Bioeng, 19, 113-117

7. Kwon YR, Youn KS (2012) Quality and antioxidan characteristics of granule tea prepared with sea tangle (Laminaria japonica) and sea mustard (Undaria pinnatifida) powder as affected by extraction method. Korean J Food Preserv, 19, 525-531

8. Hwang IG, Woo KS, Jeong HS (2011) Biological activity and heat treatment processing of foods. Food Sci Ind, 44, 56-65

9. Jeong HS, Han JG, Ha JH, Kim Y, Oh SH, Kim SS, Jeong MH, Choi GP, Park UY, Lee HY (2009)
Enhancement of anticancer activities of Ephedra sinica. Angelica gigas by ultra high pressure extraction. Korean J Medicinal Crop Sci, 17, 102-108

10. Kim CH, Kwon MC, Syed AQ, Hwang B, Nam JH, Lee HY (2007) Toxicity reduction and improvement of anticancer activities from Rhodiola sachalinensis A. Bor by ultra high pressure extracts process. Korean $\mathbf{J}$ Medicinal Crop Sci, 15, 411-416

11. Lee GJ, Choi SD (2008) Application of biological industry using high hydrostatic pressure (HHP) system. Korean J Biotechnol Bioeng, 23, 362-368

12. Saha SK, Brewer CF (1994) Determination of the concentrations of oligosaccharides, complex type carbohydrates, and glyco-proteins using the phenol sulfuric acid method. Carbohydr Res, 254, 157-167

13. Lowry OH, Rosebrough NJ, Farr AI, Randall RJ (1954) Protein measurement with the Folin phenol reagents. J Biol Chem, 193, 265-275

14. Bitter T, Muir HM (1962) A modified uronic acid carbazole reaction. Anal Biochem, 4, 333-334

15. Park SJ, Choi YB, Ko JR, Kim YE, Lee HY (2014) Enhancement of antioxidant activities of blueberry (Vaccinium ashe1) by using high-pressure extraction process. J Korean Soc Food Sci Nutr, 43, 471-476

16. Choi WY, Lee HY (2014) Enhancement of antioxidant activities of Curcuma longa leaves by ultra high pressure extraction. Korean J Medicinal Crop Sci, 22, 121-126

17. Na HS, Kim JY, Park JS, Choi GC, Yang SI, Lee JH, Cho JY, Ma SJ (2014) Characteristics of marine algae extracts using subcritical water extract method. Korean J Food Preserv, 21, 62-68

18. Fang Z, Sato T, Smith-Jr RL, Inomata H, Arai K, Kozinski JA (2008) Reaction chemistry and pahse behavior of lignin in high-temperature and supercritical water. Bioresour Technol, 99, 3424-3430

19. Koo SY, Cha KH, Lee DU (2007) Effects of high hydrostatic pressure on foods and biological system. Food Sci Industry, 40, 23-30

20. Zhang S, Zhu J, Wang C (2004) Novel high pressure extraction technology. Int J Pharm, 278, 471-474

21. Lahaye M (1991) Marine algae as sources of fibers : determination of soluble and insoluble dietary fiber contents in some sea vegetables. J Sci Food Agric, 54, 587-594

22. Grid JP, Marion C, Liutkus M, Boucard M, Rechencq E, Vidal JP, Rossi JC (1988) Hypotensive constituents of marine algae. 1 Phamacological studies of laminine. 
Plantamed, 54, 193-196

23. Jung BM, Ahn CB, Kang SJ, Park JH, Chung DH (2001) Effects of Hizikia fusiforme extracts on lipid metabolism and liver antioxidative enzyme activities in triton-induced hyperlipidemic rats. J Korean Soc Food Sci Nutr, 30, 1184-1189

24. Lee SH (2011) Current status and prospect of nutraceuticals from marine algae. Bull Food Technology, 24, 165-175

25. Lee SD, Lee KS, Okuda H, Hwang WI (1990) Inhibitory effect of crude acidic polysaccharide of Korean ginseng on lipolytic action of toxohormone-L from cancerous ascites fluid. Korean J Ginseng Sci, 14, 10-13

26. Jee HK, Cho YJ, Kim CT, Jang YS, Kim CJ (2006) Increase of solubility of Ginseng Radix by extrusion cooking. Korean J Food Sci Technol, 38, 361-368
27. Choi YJ, Hwang KH (2011) Analysis of the extraction condition of soluble acidic polysaccharides from Ginseng Marc. Kor J Pharmacogn, 42, 82-88

28. Park NY, Kim JS, Jeong YJ (2008) Effects of extraction conditions on the componential extraction of brown seaweed (Undaria pinnatifida). J Korean Soc Food Sci Nutr, 13, 321-326

29. Ministry of agriculture and forestry (2012) Material of Korean food Jeotgal fuctional investigation study. Republic of Korea

30. Noda N (1993) Health benefits and nutritional properties of nori. J Appl Phycol, 5, 225-258

31. Oishi K, Tamura Y, Kanai E (1961) Quality of Kombu, edible seaweeds belonging to the Laminariaceae. IV. Relation between quality and amino acid composition of extractives. Nippon Suisan Gakkaishi, 27, 601-605 